\title{
Virtual Reality As a Represent Of Spatial Perception Of Main Chapel Room At The Church Of Light
}

\section{Uji Virtual Reality Sebagai Representasi Persepsi Ruang Gereja UtaMa The Church Of Light}

\author{
Hendro Trieddiantoro Putro ${ }^{1 *}$ \\ Department of Architecture, Faculty of Science and Technology, University Technology of Yogyakarta ${ }^{1 *}$ \\ Hendro.trieddiantoro@gmail.com
}

\begin{abstract}
The research focused on the Virtual Reality in order to represent spatial perception. The research object was a Virtual Reality simulation of Main Chapel at The Church of Light. There was 9 spatial perception category to describe Main Chapel at The Church of Light that founded from literature study. The research used a virtual reality simulation and a semantic differential questionnaire. There are 40 students joined the research. They divided into 2 groups of architectural background groups and non-architectural background groups. They join the virtual reality simulation then tested with a semantic differential questionnaire. The research concluded with the effectiveness of Virtual Reality. The spatial perception of the main chapel at The Church of Light can be represented using Virtual Reality simulation. According to 7 spatial perception category that is represented, Virtual Reality can be categorized as an effective medium to representing spatial perception. Moreover, analyze results to6 pairs word that relate to 2 perception category that not in accordance with the literature study, specifically to the darkness and detail of the object. This could happen because of a lack of quality in Virtual Reality simulation product. The lack that produced from the low contrast effect and unmatched material reflection or miss match with the real condition.
\end{abstract}

Keywords: Spatial Perception, Main Chapel Of The Church of Light Virtual Reality Simulation, Semantic Differential.

\section{PENDAHULUAN}

Arsitektur berbicara tentang presence atau pengalaman ruang, yaitu penjabaran persepsi terhadap lingkungannya. Presence merupakan pengalaman keberadaan seseorang terhadap lingkungan. Dijelaskan Gibson (1986) dalam Steuer (1993) bahwa presence mengarah pada persepsi seseorang terhadap apa yang berada disekitarnya dan dikontrol melalui proses mental. Lebih lanjut Gibson (1986) dalam Steuer (1993) mengatakan bahwa media komunikasi memunculkan telepresence. Telepresence diartikan sebagai pengalaman keberadaan seseorang terhadap lingkungan melalui sebuah media. Pengalaman ruang tersebut disampaikan melalui sebuah media komunikasi. Media komunikasi sebagai perantara dalam penyampaian informasi, bertujuan meningkatkan keberhasilan menyampaikan ide dan mengurangi hambatan dalam berkomunikasi.

Presentasi arsitektur erat kaitan dengan visual, yaitu gambar dalam upaya menciptakan ketepatan visualisasi yang mendekati realita. Daniela Bertol (1997) dalam bukunya "Designing Digital Space: An Architect's Guide to Virtual Reality" mengatakan visualisasi menurut kronologi waktu terbagi menjadi 3, yaitu the past,the present, dan the future. The past merupakan fase yang menceritakan tentang munculnya hand-drawn image, ditemukannya dasar-dasar perspektif 
sebagai tonggak dalam menciptakan ketepatan gambar secara tiga dimensi oleh pelukis, arsitek, dan para peneliti, kemudian pengaruh warna dalam menambah kedalaman dan ketepatan dalam visualisasi gambar. The present merupakan fase dimana muncul inovasi pemanfaatan komputer dalam visualisasi arsitektur dan penggunaan teknologi pada segala bidang, munculnya aplikasi CAD (Computer Aided Design). The future berisi kemungkinan yang dapat terjadi kedepan seputar mendesain dan visualisasi.

Berkaitan dengan presentasi arsitek, Burden (1992) dalam bukunya "Design Presentation" mengatakan bahwa ketepatan dalam memilih media komunikasi, ketepatan dalam memilih jenis dan ukuran gambar, serta keterampilan dalam mengatur peralatan presentasi akan sangat menentukan keberhasilan seorang arsitek atau sebuah konsultan perencana arsitektur dalam menjual gagasan atau ide desainnya. Seperti yang telah diketahui bahwa selama ini arsitek menggunakan media, diantaranya adalah gambar sketsa, perspektif 3d, hingga animasi sebagai media komunikasinya kepada klien.

Teknologi informasi berkembang dengan pesat dalam era digital ini, salah satunya adalah dalam bidang visualisasi arsitektur. Perkembangan tersebut ditandai dengan maraknya penggunaan software di kalangan arsitektur sebagai media komunikasi. Contohnya adalah penggunaan Virtual Reality atau Virtual Environment. Mihelj (2014) menjelaskan secara sederhana Virtual Reality adalah lingkungan virtual yang memiliki tiga dimensi visual sehingga pengguna dapat berinteraksi dengan suatu lingkungan, dimana seluruhnya disimulasikan oleh komputer. Teknologi ini memiliki kelebihan dalam mendeskripsikan sebuah keadaan atau sebuah obyek, dimana visualisasi yang ditampilkan dapat dilihat dari segala sudut secara real time. Teknologi ini telah banyak digunakan sebagai media simulasi dan eksperimen, contohnya pada bidang kedokteran, simulasi pesawat dan kendaraan, hingga simulasi strategi pertahanan perang.
Cahaya merupakan salah satu faktor dalam membentuk persepsi ruang. Cahaya dapat diterima melalui modalitas visual yang kemudian diterjemahkan oleh mata menjadi gambar aktual. Tadao Ando adalah salah seorang arsitek yang memanfaatkan peran cahaya dalam karya rancangannya. Ando mengatakan bahwa cahaya merupakan faktor kontrol yang penting, contohnya pada The Church of Light. Redesain gereja, memenangkan penghargaan tertinggi arsitektur pada tahun 1995 yang terletak di Ibaraki Jepang. Ando memanfaatkan cahaya dan mengkombinasikannya dengan elemen arsitektur sebagai pembentuk persepsi ruang. Icon yang paling dikenal dari The Church of Light adalah Ruang Gereja Utama.

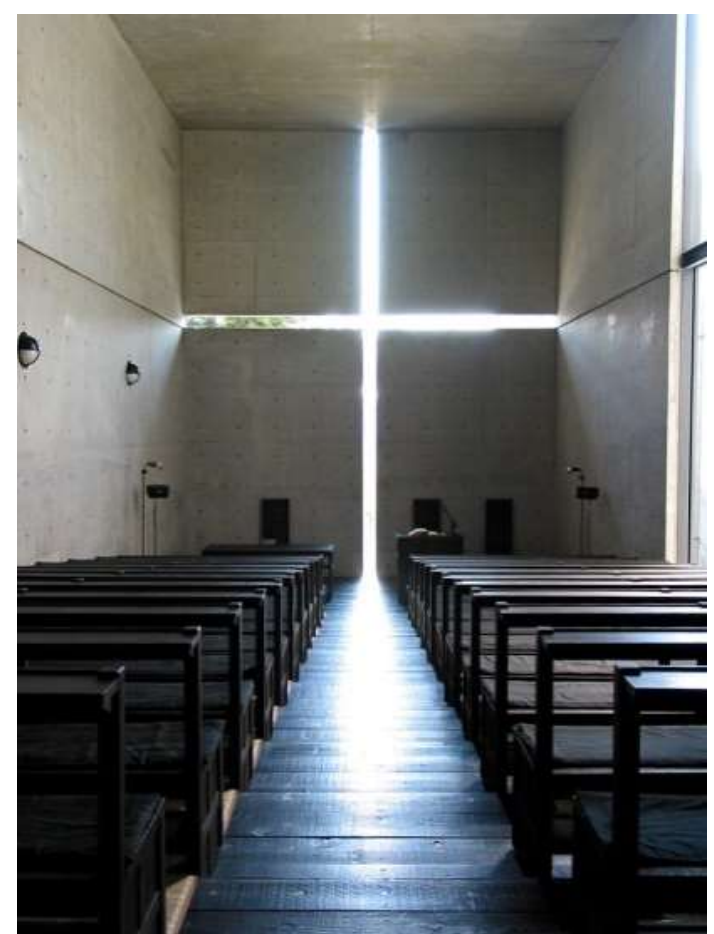

Gambar 1. The Church Of Light Karya Tadao Ando

Bentuk salib semakin terlihat ketika ada cahaya dari luar. Tadao Ando mengatakan bahwa konsep dari The Church of Light merupakan arsitektur dualitas, hubungan antara alam dengan lingkungan buatan yang berupa solid - void, terang - gelap, dan stark (kontras) - serene (fokus).

Penelitian ini berfokus pada pengujian Virtual Reality untuk menyampaikan persepsi spasial. Persepsi spasial mengacu pada kondisi ruang 
yang diuji melalui simulasi Virtual Reality. Manfaat penelitian ini yaitu sebagai evaluasi dan pengembangan media komunikasi arsitektur yang diuji melalui penilaian responden kalangan arsitektur dan non arsitektur.

\section{METODE}

Peneliti menggunakan alat ukur kuesioner berbentuk semantic differential dengan memberikan penilaian terhadap derajat kecendrungan pada pasangan kata dengan skala lima butir. Kuesioner diujikan kepada 40 mahasiswa, yaitu 20 orang mahasiswa arsitektur dan 20 orang mahasiswa teknologi informasi dan komunikasi. Responden terlebih dahulu mengikuti simulasi Virtual Reality kemudian mengisi kuesioner.

Ada 9 kategori persepsi untuk menggambarkan Ruang Gereja Utama di The Church of Light seperti Darkness, Small in dimension, Dimension ratio 1:3:1, Monochrome, Clean, quiet and calm interior space, Closed spaces, Emptiness, Spiritual and dramatic feelings. Semua persepsi didapat dan diolah dari hasil penelitian oleh Gill (2006) dan Ratkovic (2012), dan Saha (2012) seperti pada tabel 1.

Kategori persepsi ruang akan menjadi indikator penilaian. Setiap kategori diterjemahkan ke dalam 4 kata kata sifat yang berlawanan menggunakan metode semantic diferensial oleh Osgood (Osgood, Suci, \& Tannenbaum, 1957).

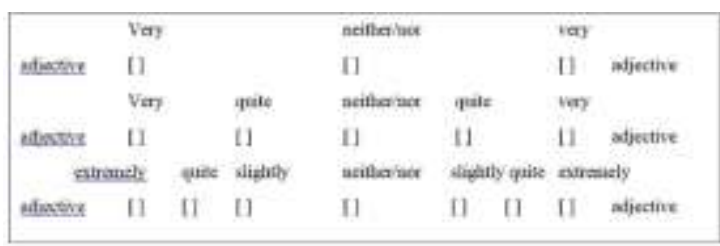

Gambar 2. Kuesioner Berbentuk Semantik Diferensial

Kuesioner berupa pasangan kata sifat saling berlawanan, dimana jawabannya tidak ada yang "salah atau benar". Dane (1990) menjelaskan keuntungan menggunakan skala semantic diferensial adalah list pasangan kata yang sama dapat digunakan untuk mengukur beberapa konsep lain. Komponen afektif dari persepsi ruang diolah dari peneltian Lam (1977). Penilaian persepsi ruang openness dan spaciousness digunakan untuk mendeteksi interaksi antara warna ruang dengan pengalaman ruang diolah dari penelitian Franz (2006). List kata persepsi penilaian untuk mengukur impresi subjektif tentang pencahayaan diolah dari penelitian Flynn et al (1979). Didapat 36 kata sifat yang berlawanan, kemudian dirancang dan dibagi kedalam 9 kategori persepsi spasial. Persepsi ruang selanjutnya dideskripsikan menjadi 4 pasangan kata berbahasa Indonesia dan Inggris pada tiap kategorinya.

Tabel 1. Pasangan Kata untuk Persepsi Ruang

\begin{tabular}{|c|c|c|}
\hline No & $\begin{array}{c}\text { Persepsi } \\
\text { Ruang Gereja }\end{array}$ & Pengertian Persepsi Ruang \\
\hline 1 & $\begin{array}{l}\text { Darkness } \\
\text { (dark into light } \\
\text { and light into } \\
\text { space) }\end{array}$ & $\begin{array}{l}\text { Menjelaskan tentang kejelasan } \\
\text { visual akan objek, berhubungan } \\
\text { dengan kondisi cahaya pada } \\
\text { lingkungan }\end{array}$ \\
\hline 2 & $\begin{array}{l}\text { Small in } \\
\text { dimension } \\
(113 m 2)\end{array}$ & $\begin{array}{l}\text { Menjelaskan impresi atau kesan } \\
\text { sebuah ruang berdasarkan } \\
\text { persepsi ukuran }\end{array}$ \\
\hline 3 & $\begin{array}{l}\text { Spiritual and } \\
\text { dramatic } \\
\text { feelings }\end{array}$ & $\begin{array}{l}\text { Menjelaskan kualitas atau } \\
\text { kemampuan konsentrasi ketika } \\
\text { melihat sebuah objek, berupa } \\
\text { keoptimalan pencahayaan } \\
\text { ruangan yang dirasakan } \\
\text { pengguna untuk beraktifitas serta } \\
\text { menjelaskan perasaan emosional } \\
\text { kaitannya dengan kondisi ruang }\end{array}$ \\
\hline 4 & Closed spaces & $\begin{array}{l}\text { Keadaan sebuah kondisi atau } \\
\text { perasaan berdasarkan kondisi } \\
\text { fisik ruangan }\end{array}$ \\
\hline 5 & $\begin{array}{l}\text { Clean, } \quad \text { quiet } \\
\text { and } \quad \text { calm } \\
\text { interior space }\end{array}$ & $\begin{array}{l}\text { Menjelaskan tingkat } \\
\text { kenyamanan emosional setuju } \\
\text { atau tidak terhadap kondisi ruang } \\
\text { yang mempengaruhi perasaan } \\
\text { kenyamanan }\end{array}$ \\
\hline 6 & monochrome & $\begin{array}{l}\text { Menjelaskan keadaan atau } \\
\text { kondisi terkait kondisi warna } \\
\text { dari objek dan lingkungan }\end{array}$ \\
\hline 7 & $\begin{array}{l}\text { Empty spaces } \\
\text { (emptiness) }\end{array}$ & $\begin{array}{l}\text { Menjelaskan perasaan saat } \\
\text { berada disebuah kondisi ruang } \\
\text { tertentu }\end{array}$ \\
\hline 8 & $\begin{array}{l}\text { Dimention } \\
\text { ratio } 1: 3: 1\end{array}$ & $\begin{array}{ll}\text { Kondisi atau kualitas } & \text { letak, } \\
\text { perletakan bentuk, } & \text { dalam } \\
\text { menjelaskan keadaan } & \text { terkait } \\
\text { organisasi antar objek } & \end{array}$ \\
\hline 9 & $\begin{array}{l}\text { Detail } \\
\text { object }\end{array}$ & 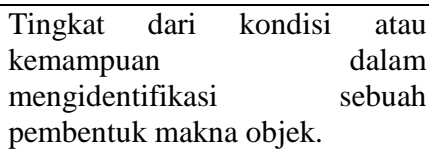 \\
\hline
\end{tabular}


Kata yang berwarna merah digunakan sebagai penanda kata persepsi ruang yang benar, seperti terlihat pada tabel 1 . Kata berwarna merah tidak ditampilkan kepada responden. Pasangan kata di kuesioner akan diacak untuk menjaga kevalidan data.

Alat penelitian yang digunakan untuk kegiatan penelitian ini adalah berupa hardware dan software. Software tersebut diantaranya sketchup dan Unity3D. Sketchup digunakan membuat model 3d. Unity 3D digunakan sebagai software untuk simulasi Virtual Reality. Alat hardware yang digunakan pada penelitian ini adalah berupa komputer dengan spesifikasi Intel Core i7-3770k Hi-Fi Z77X, 12GB of RAM, VGA NVIDIA GeForce GTX 660 2GB, dan HMD Oculus Rift DK2. Kebutuhan akan hardware ini juga dijelaskan pada artikel oleh (Ohannessian, 2015), dia mengatakan bahwa spesifikasi minimum untuk Virtual Reality ini terhitung tinggi, utamanya karena simulasi Virtual Reality membutuhkan high frame rate atau frame per detik yang tinggi untuk menciptakan pergerakan yang mulus. Selain itu hal ini berkaitan juga dengan upaya mencegah efek simulation sickness pada penggunanya.

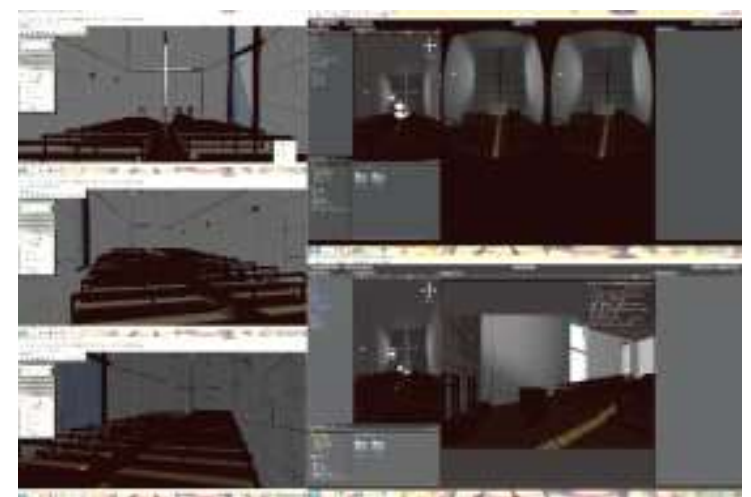

Gambar 3. Proses Pembuatan Simulasi Virtual Reality Menggunakan Sketchup dan Unity3D.

Pelaksanaan simulasi Virtual Reality yang akan diikuti responden dirancang akan dilakukan dengan posisi duduk menggunakan HMD dan gamepad untuk berinteraksi seperti terlihat pada gambar dibawah.

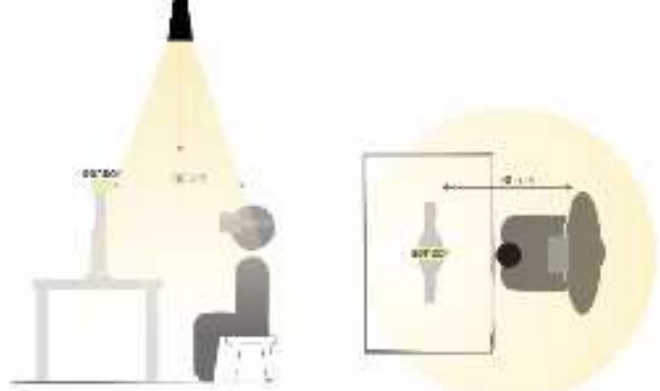

Gambar 4. Desain Interaksi Simulasi Virtual Reality

\section{HASIL DAN PEMBAHASAN}

Penelitian dimulai dengan menciptakan model $3 \mathrm{~d}$ ruang gereja utama menggunakan Sketchup kemudian proses render simulasi dilakukan dengan Unity3d. Alat simulasi Virtual Reality yang digunakan yaitu HMD dan gamepad.

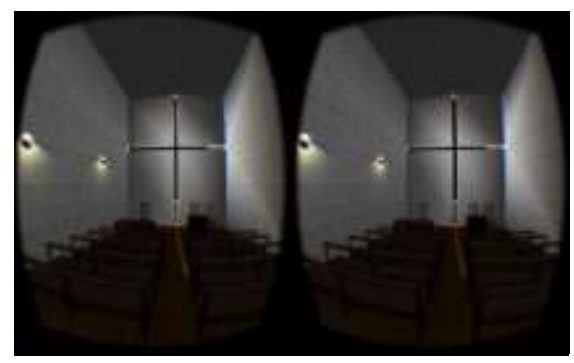

Gambar 5. Simulasi Ruang Gereja Utama di The Church of Light.

Seluruh responden adalah mahasiswa, namun yang membedakan adalah bidang studinya. Responden dalam penelitian ini adalah dari kalangan arsitektur dan non arsitektur. Kalangan arsitektur dalam penelitian ini adalah mahasiswa arsitektur. Kalangan non arsitektur adalah mahasiswa teknologi informasi. Lokasi penelitian yang dipilih adalah Lab Teknik Arsitektur UGM untuk mahasiswa arsitektur dan JDV (Jogja Digital Valley) untuk mahasiswa non arsitektur. Kuesioner diujikan kepada 40 responden, yaitu 20 orang dari kelompok arsitektur dan 20 orang kelompok teknologi informasi. Hasil kuesioner dianalisis menggunakan software SPSS 2.0 dan Microsoft Excel 2000 untuk dikonversi menjadi bentuk diagram. 


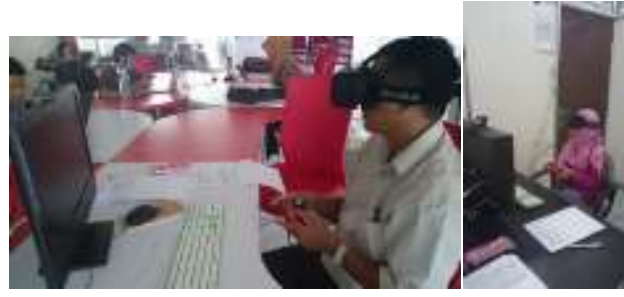

Gambar 6. Simulasi Virtual Reality di Lab Komputer UGM dan JDV

$\mathrm{Wu}$ (2006) menjelaskan, besar pengaruh peran komputer sebagai penunjang keberhasilan komunikasi arsitektur. Wu juga menjelaskan pemahaman akan penggunaan software komputer dan spesifikasi komputer yang baik akan membantu kinerja desainer dalam kecepatan memvisualkan desain. Sependapat dengan $\mathrm{Wu}$, Hubers (2007) menjelaskan visualisasi merupakan komunikasi dalam arsitektur. Komunikasi dalam paham arsitek adalah menyampaikan konsep berupa layout ruang. Selanjutnya, Fafrin (2013) melakukan penelitian tentang efektivitas media dijital sebagai alat komunikasi. Fafrin (2013) melakukan penelitian tentang persepsi masyarakat terhadap cahaya buatan dari lampu hias. Fajrin membandingkan produk software simulasi dengan software render. Penelitian tersebut menunjukkan bahwa produk software render mendapatkan nilai lebih tinggi melalui penilaian responden.

Persepsi adalah proses mengumpulkan informasi dari lingkungannya, pada kasus ini persepsi melalui media, yaitu media grafis dan VR. Selanjutnya Gifford (1997) menjelaskan bahwa faktor yang mempengaruhi persepsi atau menginterpretasi, yang pertama adalah personal, seperti latar belakang pendidikan, kedua adalah budaya, latar belakang budaya dari subjek yang mengikuti penelitian, dan faktor fisik dari subjek seperti kondisi kesehatan dan fisik. Yazdanfar et al (2014) memperkuat penjelasan bahwa ada perbedaan hasil untuk interpretasi dan persepsi sebuah tempat berdasarkan tingkat literasi visual.

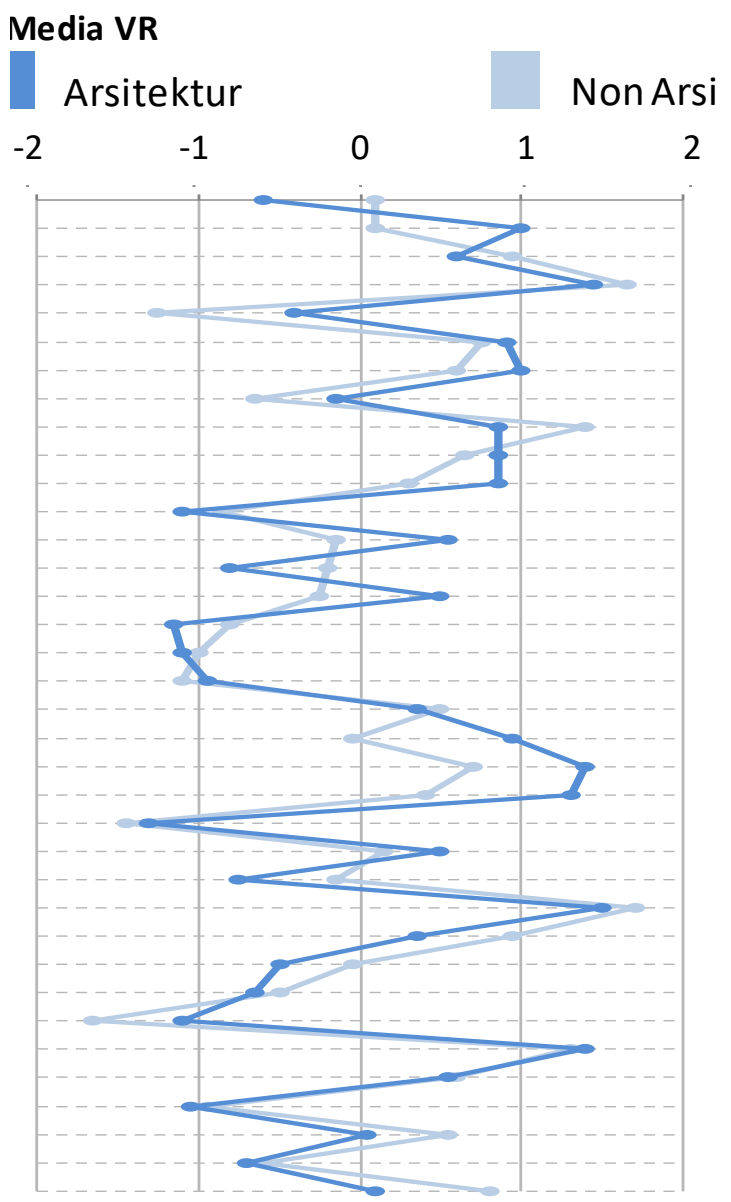

Gambar 7. Komparasi Hasil Persepsi Ruang Mahasiswa Arsitektur dan Non Arsitektur Melalui Simulasi Virtual Reality

Persepsi mahasiswa arsitektur dan mahasiswa non arsitektur terhadap ruang Gereja Utama The Church of Light melalui Virtual Reality dominan sama dengan persepsi berdasarkan hasil studi literatur. Hal ini terlihat pada gambar 7, yaitu jawaban kuesioner reponden yang telah dikonversi menjadi gambar grafik. Grafik tersebut menunjukkan bahwa garis persepsi mahasiswa arsitektur dengan non arsitektur adalah dominan searah. Maka tidak ada perbedaan persepsi yang signifikan berdasarkan bidang studi responden. Terjadinya persepsi yang sama karena responden hanya memiliki sedikit perbedaan latar belakang. Responden memiliki dasar kemampuan interpretasi dan kognisi yang sama, yaitu pemahaman persepsi melalui teknologi informatika. Hasil analisis ditemukan berbeda dengan penelitian Yazdanfar et al (2014), karena yang menjadi responden pada penelitian tersebut merupakan 
2 kelompok dengan latar belakang sangat berbeda, yaitu arsitek yang sudah terbiasa dengan pengalaman visual dan orang awam yang tidak memiliki pengalaman visual.

Berdasarkan hasil analisis responden, karena tidak ada perbedaan hasil persepsi ruang berdasarkan latar belakang, maka data responden dijadikan satu.

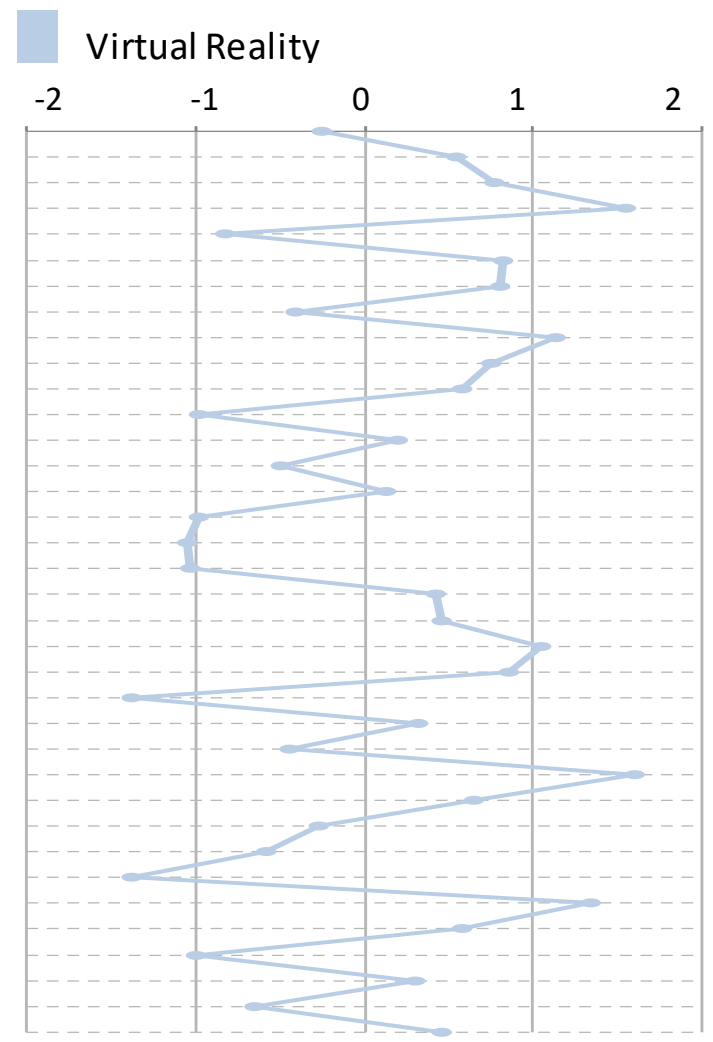

Gambar 8. Persepsi Ruang Seluruh Responden Melalui Simulasi Virtual Reality

Gambar 8 menunjukkan hasil gabungan data responden, dari gambar terlihat bahwa persepsi Ruang Gereja Utama di The Church of Light dapat tersampaikan melalui simulasi Virtual Reality. Selanjutnya, analisis menunjukkan bahwa 7 kategori persepsi ruang dapat tersampaikan atau sudah sesuai dengan studi literatur, sedangkan 2 kategori persepsi ruang tidak dapat tersampaikan dengan baik. Penjelasan persepsi Ruang Gereja Utama yang tidak dapat tersampaikan melalui simulasi Virtual Reality terlihat pada tabel 2.
Tabel 2. Persepsi Ruang Gereja Utama yang Tidak Tersampaikan Melalui Virtual Reality Berdasarkan Studi Literatur

\begin{tabular}{|c|c|c|}
\hline No. & Pasangan Kata & Persepsi Ruang \\
\hline 10 & $\begin{array}{l}\text { Silau (glare) - (non } \\
\text { glare) tidak silau }\end{array}$ & Darkness \\
\hline 19 & $\begin{array}{c}\text { Kabur (hazy) - (clear) } \\
\text { jelas }\end{array}$ & Darkness \\
\hline 14 & $\begin{array}{l}\text { Tegang (strained) - } \\
\text { (relaxed) lega }\end{array}$ & $\begin{array}{l}\text { Clean, quiet and calm } \\
\text { interior space }\end{array}$ \\
\hline 29 & $\begin{array}{l}\text { Dalam (deep) - } \\
\text { (shallow) dangkal }\end{array}$ & $\begin{array}{c}\text { Small in dimension } \\
(113 \mathrm{~m} 2)\end{array}$ \\
\hline 27 & $\begin{array}{l}\text { Kasar (bumpy) - } \\
\text { (plain) datar }\end{array}$ & Detail of object \\
\hline 36 & $\begin{array}{l}\text { Kasar (rough) - } \\
\text { (smooth) halus }\end{array}$ & Detail of object \\
\hline \multicolumn{3}{|c|}{$\begin{array}{c}\text { Catatan : Kata yang berwarna merah merupakan persepsi } \\
\text { ruang gereja utama di The Church of Light berdasarkan } \\
\text { studi literatur }\end{array}$} \\
\hline
\end{tabular}

Hasil analisis menunjukkan 6 persepsi yang tidak sesuai dengan studi literatur. Hasil serupa terjadi pada penelitian oleh (Billger, Heldal, Stahre, \& Renstrom, 2004), mereka membahas tentang persepsi warna dan ruang. Mereka membandingkan ruang asli dengan ruang virtual. Mereka mengkritisi penggunaan komputer sebagai visualisasi grafis saat ini hanya digunakan untuk menciptakan gambar supaya "terlihat bagus dan alami" tanpa memperhatikan simulasi yang benar. Metodenya adalah dengan 3 aplikasi komputer mereka menciptakan ruang dengan warna dan persepsi ruang asli, kemudian produk simulasi dibandingkan dengan penilaian kuesioner responden. Persepsi ruang asli menjadi tolak ukur penilaian. Hasil menunjukkan bahwa terjadi perbedaan signifikan antara ruang asli dengan ruang virtual, dimana produk komputer memberikan refleksi yang tidak tepat pada permukaan material, sedikit variasi kemampuan warna, dan bayangan. Hal itu menyebabkan efek kontras yang tidak nyata dan mempengaruhi persepsi ruang. Lebih detil menunjukkan bahwa beberapa area ruang yang dominan berwarna putih ternyata sulit untuk disimulasikan. Senada dengan pendapat (Billger, Heldal, Stahre, \& Renstrom, 2004), peneliti menemukan persepsi ruang gereja utama yang tidak dapat direpresentasikan secara maksimal, yaitu persepsi darkness dan detail of object. Persepsi tersebut dipengaruhi oleh kualitas produk simulasi. Simulasi berasal 
dari efek kontras cahaya dan refleksi material yang tidak sesuai dengan ruang gereja utama The Church Of Light.

Penjelasan tentang persepsi Ruang Gereja Utama di The Church of Light dikutip dari artikel (Gill, 2006) dan (Ratkovic, 2012), mereka berpendapat bahwa mereka merasakan dualitas persepsi yang sama pada ruang gereja utama. Persepsi dari sebuah ruang kecil gelap dengan bukaan (void) berbentuk salib. Bukaan tersebut memberi kesan yang kuat ketika cahaya memasukinya, yaitu kesan akan alami - buatan, gelap - terang, dan intense - kalem. Dualitas persepsi ruang gereja utama dijelaskan melalui konsep Tadao Ando. Ando ingin menciptakan ruang dengan konsep arsitektur dualitas. Ando mengatakan ingin menciptakan ruang dengan konsep dualitas, hubungan arsitektur dengan alam, gelap terang, buatan - alami, dalam usahanya memunculkan kesan spiritual. Kritikus dan fotografer karya arsitek seperti (Soni, 2010) dan (Pare, 1997) dalam ulasannya menyebutkan bahwa karya Ando seperti puisi, memainkan emosi perasaan melalui cahaya dan gelap untuk memunculkan bentuk (form), menyuguhkan kekayaan imajinasi, dan pengalaman ruang arsitektur. Misalnya di salah satu sisi ruang terasa gelap, namun terang di sisi lainnya.

\section{KESIMPULAN}

Penelitian ini menguji persepsi ruang melalui media yang diujikan kepada responden melalui simulasi ruang menggunakan simulasi Virtual Reality. Pengujian dilakukan dengan penilaian kuesioner yang berbentuk semantic differential. Objek penelitian adalah ruang gereja utama The Church Of Light. Persepsi ruang didapat dari studi literatur ruang gereja utama The Church Of Light. Ditemukan 9 kelompok persepsi Ruang Gereja Utama. Kelompok persepsi tersebut antara lain (1) Darkness (dark into light, light into space), (2) Closed space, (3) Clean, quite, and calm interior, (4) Empty spaces, (5) Detail of object, (6) Spiritual and dramatic feelings, (7) Small in dimension (113m2), (8) Dimension ratio 1:3:1, (9) Monochrome. Kelompok persepsi menjadi dasar pembuatan kuesioner. Kuesioner berbentuk semantik dijabarkan dari
9 kelompok persepsi menjadi 36 pasang kata persepsi ruang berbahasa indonesia dan inggris. Penelitian ini bertujuan untuk menjabarkan efektivitas simulasi Virtual Reality dalam merepresentasikan persepsi ruang gereja utama The Church Of Light.

Analisis menunjukkan bahwa persepsi ruang gereja utama The Church Of Light dapat direpresentasikan melalui simulasi Virtual Reality. Berdasarkan dari 7 kelompok persepsi ruang yang dapat direpresentasikan, simulasi Virtual Reality dapat dikatakan efektif. Namun analisis menunjukkan terjadinya 6 pasangan persepsi pada 2 kelompok persepsi yang tidak sesuai, yaitu pada kelompok persepsi darkness dan detail of object. Hal ini terjadi karena keterbatasan kualitas produk simulasi. Keterbatasan yang dihasilkan dari minimnya efek kontras cahaya dan refleksi material yang tidak tepat atau tidak sesuai dengan kondisi aslinya, sehingga simulasi ruang tidak dapat merepresentasikan ruang yang sesungguhnya.

Kesulitan teknis yang dijumpai selama penelitian adalah tahap persiapan penelitian, seperti persiapan alat hingga proses menciptakan simulasi ruang. Penelitian ini membuka kesempatan yang lebar bagi para peneliti di arsitektur, khususnya di bidang visualisasi menggunakan media arsitektur dijital, persepsi ruang melalui media, hingga simulasi interaksi manusia dengan komputer (human - computer interaction). Fokus dan metode lainnya adalah pada penggunaan media Virtual Reality sebagai simulasi. Penelitian lanjutan sejenis misalnya membandingkan beberapa aplikasi Virtual Reality dalam menghasilkan kualitas cahaya dan warna, penggunaan Virtual Reality sebagai media revitalisasi bangunan cagar budaya, hingga presentasi gagasan atau konsep desain bangunan maupun kawasan.

\section{REFERENSI}

Bertol, D. (1997). Designing Digital Space: An Architect's Guide to Virtual Reality. U.S: John Wiley \& Sons.

Billger, M., Heldal, I., Stahre, B., \& Renstrom, K. (2004). Perception of Color and Space in Virtual Reality: a Comparison between a Real Room and Virtual Reality Models. Human Vision and Electronic Imaging IX. IX, pp. 90-98. San Jose, CA: SPIE 5292. 
Burden, E. (1992). Design Presentation: Creating Marketing and Project Proposal Second Edition. New York: Me Graw Hill Inc.

Dane, F. C. (1990). Research Methods. California: Brooks/Cole Publishing Company.

Fafrin. (2013). Persepsi Masyarakat Terhadap Hasil Simulasi Program Dialux dan 3Ds Max Dalam Memproduksi Cahaya Studi Kasus Galeri Furniture D-Bodhi. MSc Thesis, Universitas Atma Jaya, Magister Teknik Arsitektur, Yogyakarta.

Flynn, John E, Hendrick, Spencer, \& Martyniuk. (1979). A Guide to Methodology Procedures for Measuring Subjective Impressions in Lighting. A Research Project Report of The Illuminating Engineering Research Institute.

Franz, G. (2006). Space, color, and perceived qualities of indoor environments.

Gibson, J. J. (1986). The Ecological Approach to Visual Perception. New York: Psychology Press.

Gill, S. S. (2006). A Study of The Characteristics of Natural Light in Selected Building Designed by Le Courbusier, Louis I. Khan, and Tadao Ando. Texas A\&M University, Department of Architecture. Texas A\&M University.

Hubers, J. (2007). COLlaborative Architectural Design. Ph.D. Thesis, Delft University of Technology, Faculty of Architecture, Netherlands.

Lam, W. M. (1977). Perception and Lighting as Formgivers for Architecture. New York: McGraw-Hill Book Company.

Mihelj, M., Novak, D., \& Beguš, S. (2014). Virtual Reality Technology and Applications (Vol. 68). (S. G. Tzafestas, Ed.) New York, London: Springer.

Ohannessian, K. (2015, May 18). Oculus Rift's PC Requirements Are Virtual Reality's Achilles' Heel. Retrieved July 23, 2015, from Tech Forecast: http://www.fastcompany.com/3046376/te ch-forecast/oculus-rifts-pc-requirementsare-virtual-realitys-achilles-heel

Osgood, C. E., Suci, G. J., \& Tannenbaum, P. H. (1957). The Measurement of Meaning.
United State of America: University of Illinois Press.

Pare, R. Tadao Ando: The Colours of Light. Richard Pare - Tadao Ando: The Colours of Light. Museums Assistance Program of the Department of Canadian Heritage, Rome.

Ratkovic, I. (2012, March 19). Tadao Ando. Retrieved from www.arhitekton.net: It is said that the Church of the Light http://www.arhitekton.net/tadao-ando3/?lang=en\#sthash.s8BSrCbm.dpuf

Saha, P. (2012, December 9). Church of Light. Retrieved from architectureassociate.blogspot.com: http://architectureassociate.blogspot.com/ 2012/12/church-of-light.html

Soni, A. K. (2010). Understanding The Poetic of Architecture. Guru Gobind Singh Indraprastha University, University School of Architecture and Planning, Kashmere Gate, New Delhi.

Steuer, J. (1993, October). Defining Virtual Reality: Dimensions Determining Telepresence. Social Responses to Communication Technologies, 73-93.

$\mathrm{Wu}$, H. (2006). Virtual Reality - Improving The Fidelity of Architectural Visualization. MSc Thesis, Texas Tech University, Texas.

Yazdanfar, S. A., Heidari, A. A., \& Aghajari, N. (2014). Comparison of Architects' and Non-Architects' Perception of Place. Procedia - Social and Behavioral Sciences 170, 690-699. 